\section{S.E. Lobben svarer:}

Tore Guttebergs forespørsel om hva slags løsninger og modeller man bør velge når det gjelder elsykkel, er et godt spørsmål med mange svar.

Etter hvert kommer alle slags sykkeltyper som elsykkel, fra god gammel damesykkel med lavt innsteg til fatbike for norsk vintersykling, foldesykkel for togpendlere og fulldemper for Jotunheimen.

Det finnes hovedsakelig tre forskjellige motortyper: krankmotor og hubmotor i forhjul eller bakhjul. Batterier kommer med varierende teknologi, kapasitet og plassering. Man kan kjøpe ombyggingssett eller fiks ferdige elsykler. Når det gjelder pedalsensor, kommer de i to varianter, bevegelsessensor eller torquesensor.

Personlig foretrekker jeg krankmotor, torquesensor og lavt midtplassert batteri. Det gir mulighet for å utnytte sykkelens girsystem, torquesensoren gir en naturlig sykkelfølelse, og lavt midtplassert batteri bidrar til gode kjøreegenskaper. Jeg kjenner andre elsyklister som har andre preferanser enn meg.

Prøv før du kjøper, er sannsynligvis et godt råd.

\section{Stian Ellingsen Lobben}

stianlobben@gmail.com

\author{
Stian Ellingsen Lobben (f. 1978) er fastlege ved Nytorget Legesenter, \\ Stavanger. \\ Ingen oppgitte interessekonflikter.
}

Dette er en redigert versjon av debatten, publisert som rask respons på nett 11.10.2013. http://tidsskriftet.no/article/3059062/

\section{Loven og budsjettet}

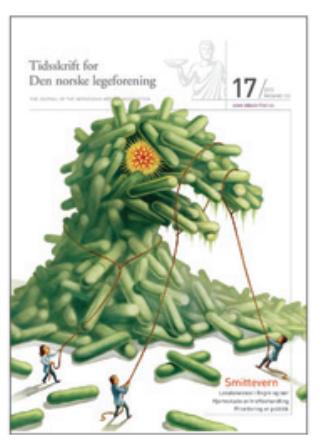

Marit Halvorsen har en velskrevet og oversiktlig fremstilling i Tidsskriftet $\mathrm{nr}$. 17/2013 (1). Jeg minner om Sylvia Brustads tordentale i Stortinget hvor hun beskyldte legene for «svik mot demokratiet» når de ikke maktet å løse lovpålagte oppgaver innenfor de budsjettene Stortinget hadde vedtatt. Det ble foruroligende taust både fra fagfolkene og de øvrige politikerne.

Konklusjonen i siste setning er imidlertid ikke ubetinget riktig, og følger ikke nødvendigvis av fremstillingen: Det er loven, og ikke budsjettet, som skal bestemme omfanget av helsetjenesten (min utheving). Hvis vi fjerner imperativet «skal» fra konklusjonen, slik at den lyder: Det er loven, og ikke budsjettet, som bestemmer omfanget av helsetjenesten, ser vi at den blir åpenbart feil. Både loven og budsjettet er strukturelle begrensninger som bestemmer omfanget av helsetjenestene. En bedre formulering av konklusjonen som er mer i tråd med fremstillingen vil kanskje være: Siden det er den lovgivende forsamlingen som også vedtar budsjettene, er det den lovgivende forsamlingens plikt å bevilge budsjetter som gjør det mulig for fagfolkene å overholde loven. Det er dette ansvarsforholdet som pulveriseres med foretaksmodellen.

Men denne konklusjonen krever at lovgiverne, som bevilgende myndighet, har tilstrekkelig informasjon om forventede behov og kostnader til å kunne forsikre seg om at de som bevilgende myndighet ikke bryter loven. Dette er en situasjon hvor det er mangfoldige interessekonflikter. Da handler det også om makt. Måten politikerne har valgt å løse denne situasjonen på, er altså å innføre den industrielle mål- og resultatstyringen som overordnet politisk, økonomisk og administrativ styringsideologi og metode for Norge.

Implementering av den markedsorienterte, industrielle mål- og resultatstyringsmetoden gir sammenliknbare data mellom offentlig og privat virksomhet, og legger således til rette for anbud, konkurranseutsetting og privatisering. For at dette kvasimarkedet skal fungere, må politikerne utdype og presisere «kundenes» rettigheter i lovs form, slik at «kunden fritt kan velge» hvilken leverandør i «det frie markedet» som skal oppfylle rettigheten på statens bekostning. I praksis vil det si å lovfeste mye av det Marit Halvorsen henviser til som «andreordens beslutninger», som ideelt sett er en kompetanse som tilhører fagfolkenes situasjonsbestemte faglige skjønn.

I politisk praksis er altså rettsliggjøring, mål- og resultatstyring og markedsorientering elementer i samme strategi eller veivalg. Men alle tre elementene i strategien virker gjensidig kostnadsdrivende og er ikke økonomisk bærekraftig. Resultatet blir nødvendigvis en dyrere og mindre omfattende helsetjeneste, med mer bruk av egenandeler og større muligheter for de velstående til å kjøpe seg privilegier gjennom private tilleggsforsikringer.

Svaret på utfordringene må etter min oppfatning heller være å begrense utdypingen og presiseringen av pasientrettighetene, avsverge markedsorienteringen og den kostnadsdrivende og faglig fremmedgjørende mål- og resultatstyringsideologien, og fokusere på kvalitet innenfor et forvaltningsregime. Det innebærer at politikerne skal styre mer gjennom budsjettene som de står ansvarlige for ved valg, og mindre gjennom stadig mer detaljerte rettighetslover og et ansvarspulveriserende kvasimarked som «automatisk» skal balansere forholdet mellom tilbud og etterspørsel. Et slikt svar vil blant annet gjøre det enklere å plassere ansvaret for de forskjellige typene prioriteringer riktig, og tydelig for alle.

\section{Johan Nygaard idedetskjer@yahoo.no \\ Johan Nygaard (f. 1953) er skribent. Ingen oppgitte interessekonflikter. \\ Litteratur \\ 1. Halvorsen M. Prioritering hører hjemme i politikken. Tidsskr Nor Legeforen 2013; 133: 1838-40.}

Dette er en redigert versjon av debatten, publisert som rask respons på nett 19.9.2013. http://tidsskriftet.no/article/3061584/

\section{Budsjett eller overslag}

I Tidsskriftet nr. 17/2013 tar Marit Halvorsen i praksis til orde for å fjerne budsjettrammer og gå over til å styre gjennom juridiske rammeverk (1). Dette mener jeg er udemokratisk og vil gi dårligere kvalitet. Det har tjent Norge vel at politikere vedtar rammene, mens ledere og fagpersoner i tjenesten skal få best mulig tjenester til innbyggerne for det som bevilges.

Jeg mener at Halvorsen undervurderer politikernes ansvar for helheten i statens pengebruk, og overvurderer politikernes evne til å detaljregulere og kostnadsberegne tjenester på individnivå. At innbyggerne har kontroll på statsbudsjettet er avgjørende for å ha legitimitet for å kreve inn skatter, og for at ulike sektorer skal akseptere hvor store ressurser de er tildelt.

Når Halvorsen slår fast at «ikke budsjettet skal bestemme omfanget av helsetjeneste», undergraver det etter mitt syn århundregamle prinsipper om å vedta et samlet budsjett basert på prioriteringer. Halvorsen mener at «størrelsen på helsetjenestens budsjett må bestemmes ut fra hvilke tjenester befolkningen tilbys og hvilken kvalitet tjenestene skal ha». I så fall gir vi Stortinget en umulig oppgave. Deler av budsjettet vårt reguleres slik i dag gjennom trygderettigheter, men jeg vil advare mot et system hvor alle offentlige tjenester reguleres av rettigheter som gir automatiske bevilgninger. Skulle hele budsjettet håndteres slik, vil man først på slutten av året vite hvor mye penger som er brukt, og man må i etterkant øke skattene eller oljepengebruken. 
Et system hvor alle enkelttjenester skal lovreguleres i stedet for å rammestyres vil gi et voldsomt byråkrati for å kostnadsberegne og vedta de ulike tjenestetilbudene, for deretter å kontrollere at tjenestene er levert i riktig omfang til riktig pris. Selv med omfattende regulering vil et helsesystem uten kostnadsrammer med nærmest uendelig etterspørsel kunne føre til overbehandling og mangel på helsepersonell. I tillegg vil det true hovedformålet med statsbudsjettet, nemlig å holde kontroll på totaliteten i norsk økonomi. Dårlig budsjettkontroll fører ofte til arbeidsledighet, høy rente, sosial ulikhet og industrinedleggelser som heller ikke er godt for helsen.

Jeg mener derfor at vi skal hegne om et system hvor Stortinget i hovedsak bevilger rammer til sykehus og kommuner, og lar de som er nærmest oppgavene, gjøre prioriteringene. Prioriteringer skjer på ulike nivåer og ofte i samspill mellom flere aktører med ulike interesse- og ansvarsområder. Stortinget vedtar skattenivå, total pengebruk og fordeling mellom ulike samfunnsområder. Sentrale helsepolitiske myndigheter og forvaltning styrer de overordnede prioriteringene gjennom å tilrettelegge økonomiske, rettslige og organisatoriske rammevilkår. Samtidig har statlige fagmyndigheter et ansvar for å understøtte gode prioriteringer gjennom veiledere og retningslinjer.

Norge har lang tradisjon for å jobbe systematisk med spørsmål rundt prioriteringer i helsetjenesten. Spørsmålet om prioritering har fått ny oppmerksomhet blant annet knyttet til innføring av nye og kostbare kreftmedisiner, og helseministeren nedsatte $i$ år et offentlig utvalg som kan utrede hvordan vi best prioriterer helsetjenestens ressurser.

Ett av hovedpunktene i mandatet er at utvalget skal foreslå konkrete prioriteringsverktøy som kan understøtte systematisk bruk av dagens prioriteringskriterier. I mandatet er utvalget bedt om å sørge for bred involvering av alle relevante aktører. Vi må alle jobbe godt sammen for å sikre gode demokratiske prosesser for prioriteringer $\mathrm{i}$ helsesektoren i tiden som kommer.

\section{Robin Kåss}

robin_kass@hotmail.com

Robin Kåss (f. 1977) er lege og lokalpolitiker i Porsgrunn

Ingen oppgitte interessekonflikter.

\section{Litteratur \\ 1. Halvorsen M. Prioritering hører hjemme i politikken. Tidsskr Nor Legeforen 2013; 133: $1838-40$}

Dette er en redigert versjon av debatten, publisert som rask respons på nett 2.10.2013. http://tidsskriftet.no/article/3061584/

\section{Halvorsen svarer:}

Forhenværende statssekretær Robin Kåss tillegger meg de underligste synspunkter. Hvordan han greier å lese ut av min kronikk at jeg foreslår å «fjerne budsjettrammer, og gå over til å styre gjennom juridisk rammeverk», at jeg «undervurderer politikernes ansvar for helheten i staten pengebruk», «overvurderer politikernes evne til å detaljregulere og kostnadsberegne tjenester på individnivå» og at jeg vil ha et system der «alle enkelttjenester skal lovreguleres i stedet for å rammestyres», er ubegripelig.

La meg kort og enkelt gjenta hva jeg skrev: Lovreglene som omhandler borgernes rett til offentlige helsetjenester, er omfattende. Det er bare de unødvendige, unyttige, lite virksomme og ekstremt kostbare behandlingstiltakene som er unntatt fra syketrygdens dekningsområde, i tillegg til rent kosmetisk indisert behandling og en del av tannhelsetjenestene. Dette er et politisk valg som er gjort med hensikt. For at disse rettighetene skal kunne oppfylles, må de følges opp med bevilgninger. Hvis våre politikere mener at helsetjenesten er for kostbar, må de ta en beslutning om hvilke typer tjenester som ikke skal dekkes, eller bare dekkes delvis. Spørsmålene om hvilke helsetjenester som kunne ligge utenfor syketrygdens dekningsområde, ble diskutert bl.a. av Lønning IIutvalget (NOU 1997: 18). Jeg var sekretær for utvalget. Oppfølgingen av utvalgets arbeid, prioriteringsforskriften, innskrenket så langt jeg kan skjønne ikke syketrygdens dekningsområde.

Helsetjenesten styres gjennom juridisk rammeverk fordi helsetjenesten i Norge er lovfestet. Stortinget kan ikke se bort fra de lovene det selv har vedtatt når budsjettet fastsettes. Selvsagt skal vi ha et helsebudsjett, selvsagt vil det være styrende for utformingen av helsetjenestetilbudet og de konkrete tjenestene som ytes, men budsjettet må være realistisk. Det må svare til hva loven forutsetter. Hvis loven forespeiler befolkningen en heldekkende helsetjeneste, mens budsjettet bare tillater en delvis dekkende tjeneste, mister den offentlige helsetjenesten troverdighet. Det er ikke bra.

Politikerne, dvs. Stortinget, har alt ansvar for statens pengebruk i den forstand at det er Stortinget som er bevilgende myndighet. Stortinget har ansvar for å gi helsetjenesten tilstrekkelige bevilgninger. Stortinget skal gi overordnede bestemmelser om hvilke tilbud den offentlige helsetjenesten skal omfatte, og ikke prioritere på individnivå.

Det er forskjell på å fastsette et volum på et gode og å fordele godene på individer. Stortinget har bestemt at volumet på helsetjenesten skal være «øyeblikkelig hjelp» og «nødvendig helsehjelp». Helsepersonell skal fordele de tilgjengelige helseressursene på pasientene. Retningslinjene de skal fordele etter, er ikke særlig klart utformet, men forsvarlighetsprinsippet må til sjuende og sist være det avgjørende. Hvis ressursene ikke strekker til, må helsepersonell la være å gi øyeblikkelig hjelp til noen, eller la være å gi nødvendig hjelp til noen andre. Hvis pasientene som har krav på den ene eller den andre hjelpen, ikke får slik hjelp, kan det være uforsvarlig. Den som ikke yter hjelpen, handler i så fall ulovlig. Det er en utålelig situasjon for autorisert helsepersonell å måtte velge mellom å bryte budsjettet eller å bryte loven. Men det er virkeligheten for mange som arbeider innenfor den offentlige helsetjenesten. Mitt råd til den som måtte komme i en slik tvangssituasjon, er å holde loven og heller bryte budsjettet. Loven er en høyere rettskilde enn direktivet fra direktøren.

\section{Marit Halvorsen}

marit.halvorsen@jus.uio.no

Marit Halvorsen (f. 1957) er professor i rettsvitenskap ved Institutt for offentlig rett, Universitetet i Oslo. Hun har arbeidet i skjæringsfeltet mellom jus og medisin siden 1990.

Ingen oppgitte interessekonflikter.

Dette er en redigert versjon av debatten, publisert som rask respons på nett 11.10.2013. http://tidsskriftet.no/article/3061584/

\section{Opphavet til ordet «karantene»}

Erlend Hem har en interessant artikkel om ordet «karantene» i Tidsskriftet nr. 17/2013 (1). Hem skriver at opphavet til ordet «karantene» er det italienske «quaranta» som betyr tallet 40 .

Som tidligere utenlandsstudent er jeg av en annen oppfatning. Karantenetiden for skip med mulig smitte om bord var 41 dager. Ordet «karantene» skulle komme av det franske «quarante-et-un», altså 41. Fransk var jo som kjent verdensspråk og diplomatspråk før engelsk overtok. Uttrykk som «pan» og «mayday» i dagens maritime nødprosedyrer har sin opprinnelse $\mathrm{i}$ «je suis en panne» og «m'aider».

\section{Kolbein A. Finsnes}

kolbein.finsnes@lyse.net

Kolbein A. Finsnes (f. 1937) er pensjonert øre-nese-hals-lege.

Ingen oppgitte interessekonflikter. 